\title{
A BEGINNERS GUIDE FOR VIDEO PRODUCTION
}

\author{
DISCLAIMER
}

This report was prepared as an account of work sponsored by an agency of the United States Government. Neither the United States Government nor any agency thereof, nor any of their employees, makes any warranty, express or implied, or assumes any legal liability or responsibility for the accuracy, completeness, or usefulness of any information, apparatus, product, or process disclosed, or represents that its use would not infringe privately owned rights. Reference herein to any specific commercial product, process, or service by trade name, trademark, manufacturer, or otherwise does not necessarily constitute or imply its endorsement, recommendation, or favoring by the United States Government or any agency thereof. The views and opinions of authors expressed herein do not necessarily state or reflect those of the United States Government or any agency thereof.

\section{Energy Task Force of the Urban Consortium for Technology Initiatives}




\section{PREFACE}

\section{URBAN CONSORTIUM ENERGY TASK FORCE RESEARCH}

THE URBAN CONSORTIUM (UC) is a special network of the Nation's largest cities and urban counties brought together by PTI to find new solutions to their common concerns. The UC provides a creative forum where elected and appointed officials can identify, test, and validate practical ways to improve the provision of public services while generating new revenue opportunities. With staff, management, and business services provided by PTI, the UC addresses the critical needs of large local governments through its three task forces: Energy, Environment, and Telecommunications and Information.

The Urban Consortium Energy Task (UCETF) has 20 members and was established to improve urban energy management and decision-making through applied research and technology transfer. The UCETF focuses on developing and sharing new approaches and innovative solutions to energy management problems with local governments. Projects are organized in thematic units and co-managed by a member of the Task Force.

A description of the 1991 program Units and projects are:

\section{ALTERNATIVE VEHICLE FUELS AND TECHNOLOGIES (AVF)}

Alternative vehicle fuels offer a very strong potential to aid in the reduction of U.S. dependence on foreign oil supplies, with the resulting benefits of decreased air pollution in urban areas. Local governments can play an instrumental role in realizing this potential through practical applied research and highly visible demonstrations of alternative fuels and technologies. Issues addressed this year include identifying (a) intensive and credible market development efforts based on an applied research and demonstration program that combines reliable technology with experience-tested applications, environmental and energy diversity benefits, and (c) institutional and infrastructure barriers. The 1991 AVF unit consists of:
Broward County, FL -- Dual-Fuel Conversion Demonstration and Technology Transfer Project

New York City, NY -. Alternative Fuel Vehicle: Financing Issues

Denver, CO -. Technical and Market Comparison Between H2/CNG (Hythane), Electric Hybrid, and $C$ G Fueled Vehicles

Denver, CO -- An Alternative Fuels Fleet Evaluation System -- A Transfer Project

Detroit, MI -- Analysis of Institutional and International Limitations for Alternative Fuel Vehicles

Washington, DC -- Comparison of Energy Consumption, Energy Savings, and Environmental Effects of EVIPV vs. Conventional Gasoline Vehicle

\section{ELECTRICITY MANAGEMENT}

Urban interests for electricity management focus on means to maintain stable, secure and reasonably priced supplies of electric energy. Approaches include procedures for better demand management, application of "least cost" planning concepts, appropriate use of decentralized and/or small power production facilities, improved end-use efficiency, and developing sound structures for cooperative action among municipalities and energy utilities. Urban strategies include support for decentralized "small" power production, along with better demand management and improved end-use energy efficiency. The successful development and implementation of such strategies will require close cooperation with the utility industry and will address topics in areas of institutional relations, source flexibility, and demand-side management. The 1991 Electricity Management Unit consists of:

Albuquerque, NM -- Alternatives to Traditional Rate Setting

Chicago, IL - Integrating Innovative Supply and Efficiency Techniques

Chicago, IL -. The Chicago Energy Management Cooperative

Dade County, FL -. Energy Cost Reduction Through Resource Recovery 
Detroit, MI -- Hydraulic Waste Energy Recovery (Phase II) City of Detroit Water Distribution System

San Jose, CA -- Utility/Local Government Partnership to Increase Energy Conservation in New Construction

\section{ENERGY EFFICIENT FACILITIES}

Activities involving energy efficient facilities are at present, part of a national effort to achieve maximum cost-effective energy productivity in the building sector. There exists a need for collaboration between local government officials responsible for energy and environmental programs and other local government officials responsible for facilities, as well as the Federal officials and private sector groups, e.g. utilities. New technologies and management/administration practices to advance energy efficiency in facilities require major partnership efforts and transfer programs. Multi-family housing that has a large concentration of low-income families presents a unique challenge to lowering energy costs and maintaining energy efficient facilities. Projects in this unit are:

Boston, MA -- Neighborhood Energy Efficiency Outreach Partnership

Columbus, $\mathrm{OH}$-. Energy Efficiency and Indoor Air Quality: Solutions for Fire Stations

Louisville, KY -- Partnership Approach to Energy Efficiency in Non-Profit Facilities Montgomery County, MD -- Technology Transfer of Building Energy Design Guidelines

New Orleans, LA -. Residential Utility Costs Comparative Study

Phoenix, AZ -- Variable Frequency Drive Applications Guide

Portland, OR -- Energy Savings Through Operation and Maintenance Training in the Low-Income Multi-Family Sector

Washington, DC -- Comparison of Two Techniques for Identifying Energy Conservation Measures in Low Income Homes

\section{ENERGY, ENVIRONMENT and ECONOMIC DEVELOPMENT}

This an area that has both visionary and immediate practical emphases on the definition and evaluation of realistic strategies and actions to support energy-sustainable and environmentally responsible communities. Emphases include uses for renewable energy, practical domestic supply and conservation alternatives, and the synthesis of energy concerns with wider local government interests in economic development, environmental quality, and internal cost control. Urban strategies to improve energysustainability require attention to both broad based institutional changes, as well as specific projects designed to encourage the application of appropriate technology and community development practices. The "Sustainable Communities" project has involved three municipalities with State agency, Lawrence Berkeley National Laboratory, and a formal advisory committee with broad national representation. Projects under this unit are:

Austin, TX -- Energy Star Sustainable Rating Program

Phoenix, AZ -. Impact of Heat Island on Cooling and Environment: A Demonstration Project

Pima County, AZ -- Tucson Solar Village - Project Management

Portland, OR -- Sustainable City Transfer Project

San Francisco, CA -- Neighborhood Energy/Economic Development at South Bayshore

San Francisco, CA -- Sustainable City Transfer Project

San Jose, CA -- Sustainable City Transfer Project

Seattle, WA -- Coordination of Energy and Air Quality (CEAM)

Seattle, WA -- Bicycle Program -- Urban Trails System

Tucson, AZ .. Local Government Involvement in Long Term Resource Planning for Community Energy Services

Reports from each of these research projects, including this report, aie specifically designed to aid the transfer of proven experience to other local governments. Readers interested in obtaining any additional reports or further information about the Urban Consortium Energy Task Force and the Urban Consortium should contact:

Energy R\&D Program

Public Technology, Inc.

1301 Pennsylvania Avenue, NW

Washington, DC 20004

$1-800-852-4934$ 


\section{ACKNOWLEDGEMENTS}

The project staff wish to express their appreciation to the many individuals and organizations who assisted with the production of the videos and the research for this report.

Special thanks are due to Dan Patterson, the City of Seattle's Video Director, for his work scripting, scheduling, and editing both the Household Hazardous Waste and Business Waste Consultation videos. Thanks to Shirli Axelrod, Seattle Solid Waste Utility, Henry Draper, King County Solid Waste Division, Todd Yerkes, Seattle-King County Health Department, and David Galvin and Ray Carveth, Municipality of Metropolitan Seattle, for their technical expertise and guidance throughout the project.

Warmest thanks to my colleagues - particularly Henry Sharpe, Bill Elmelund and Bonita Chinn - for their assistance and cooperation.

Finally, my appreciation to Bob Miller, Urban Consortium Energy Task Force Unit Manager, for his guidance and insights in conducting the project.

\section{Project Manager}

Donald A. Seeberger 


\section{CONTENTS}

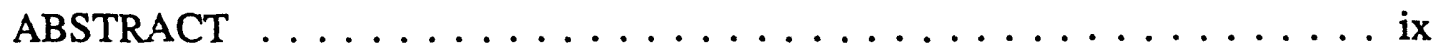

Background ...................... ix

HHW Collection Facilities $\ldots \ldots \ldots \ldots \ldots \ldots \ldots$ ix

Small Quantity Generators .................... x

Program Purpose $\ldots \ldots \ldots \ldots \ldots \ldots \ldots \ldots \ldots \ldots \ldots \ldots$

Report Organization .................... xi

CHAPTER 1: PROGRAM DESCRIPTION

Household Hazardous Waste Collection Facilities:

Fixed-Site Facilities $\ldots \ldots \ldots \ldots \ldots \ldots$

Mobile $\mathrm{HHW}$ Facilities $\ldots \ldots \ldots \ldots \ldots \ldots \ldots \ldots$

Business Waste Consultations .................. 4

Sharing Information .................... 6

\section{CHAPTER 2: LESSONS LEARNED}

Defining the Message $\ldots \ldots \ldots \ldots \ldots \ldots \ldots$

Is Video the Best Media for the Message? . . . . . . . . . . . 7

Who's the Audience? . . . . . . . . . . . . . . . . . . . 8

Narrowing the Message $\ldots \ldots \ldots \ldots \ldots \ldots \ldots$

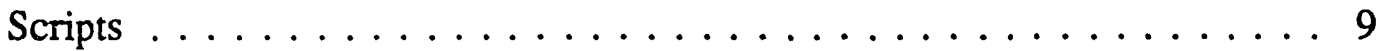

Scripts and Reality ...................... 10

Getting the Message Across $\ldots \ldots \ldots \ldots \ldots \ldots$

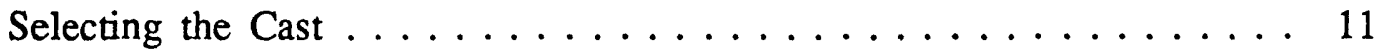

Script Approval ......................... 12

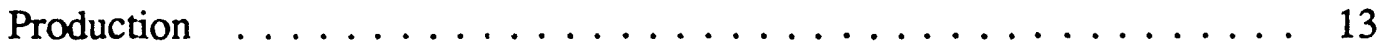

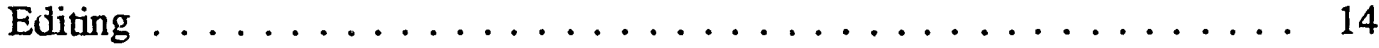

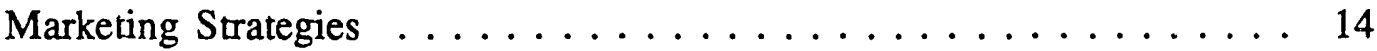

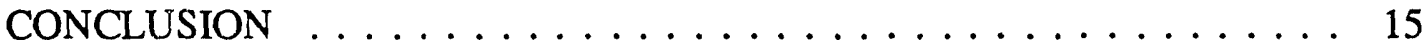

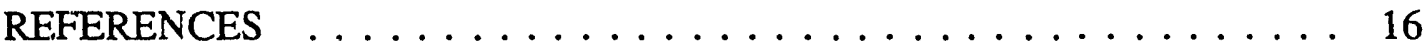

APPENDIX A ....................... 17 


\section{ABSTRACT}

\section{BACKGROUND}

The Seattle-King County Hazardous Waste Management Plan provides the framework for an intensive effort to keep Household Hazardous Waste (HHW) and Small Quantity Generator (SQG) wastes from entering the municipal solid and liquid waste streams. Many innovative programs for managing small sources of hazardous waste have been developed in response to the Plan. With the assistance of Urban Consortium grants, the City of Seattle has researched and developed a series of reports describing the planning, operation and evaluation of the plan's HHW collection programs. Three of the Plan's programs of particular interest to other jurisdictions are the fixed site and mobile HHW Collection Facilities, and the Business Waste Consultations provided to SQG's. In 1991, Seattle received an Urban Consortium grant to produce two videos showing how the HHW Collection Facilities and Business Consultations programs work. This report provides an overviews of the video development and production process and a discussion of the lessons learned by the staff directing the production.

\section{HHW Collection Facilities}

Each year Seattle-King County HHW collection programs are host to government officials from across the country, who are examining alternative collection and disposal 
methods for hazardous materials found in residential solid waste. HHW facility tours provide visitors with an overview of the physical lay-out of the site and buildings; customer services; sorting, packaging, and storage of the wastes; disposal options; and safety features. Visiting the collection sites is a costly method of gathering decisionmaking information for a jurisdiction. Yet, many officials are hesitant to commit limited resources to a HHW collection program without first examining facility options and seeing how various facilities function.

\section{Small Quantity Generators}

The Business Waste Consultation Program works with business associations to develop and disseminate industry-specific waste reduction and disposal information. To gather industry specific information, businesses typical of their trade are recruited through the business associations to be visited by a waste consultation team. Businesses volunteering to participate in the waste consultation program are assured that they will not be targeted for enforcement actions but will be provided with guidance for bringing identified problems into compliance. Team members represent federal, state and local agencies that have health and safety regulatory authority over the business' operations. The consultation team members inspect a business' waste handling practices and note problem areas. Team members are encouraged to share "what they look for" during regular inspections and to discuss their findings with the business. Information gathered from the business inspections is compiled into a trade-specific resource guide; the guide is distributed to the association's members and other businesses through the regulatory agencies.

The Business Waste Consultations are an innovative approach to bringing together regulatory agencies and businesses to examine waste reduction and disposal issues for the purposes of eduction. Information shared during the consultations often brings out conflicting regulations that are difficult for businesses to get resolved. The consultation teams seek to resolve regulatory conflicts within their authority, and to examine methods for making regulations compatible among agencies. The success of the program to resolve regulatory conflicts has created interest from state and local authorities throughout the United States. 


\section{PROGRAM PURPOSE}

The purpose of the City of Seattle's Year 12 Urban Consortium grant was to produce two video tapes showing the key elements of the Household Hazardous Waste Collection and the Business Waste Consultation programs. The videos were written to provide the viewer with an opportunity to actually see the programs in operation and answer specific technical questions. Copies of the videos are available from the City of Seattle and Public Technology, Inc.

This report provides a description of the lessons learned by the City of Seattle's Office for Long-range Planning during the video production process. The report is structured to assist other communities with their planning and production of information videos about government programs.

\section{REPORT ORGANIZATION}

The product of Seattle's Year 12 Urban Consortium grant is the HHW and Business Waste Consultation video tapes. This report presents: 1) a brief description of each video tape, and 2) the lessons learned by City staff during the planning, scheduling, and production of the videos. This report is not meant to be a "how to" guide for video production, but a sharing of some common mistakes novice film makers may tend to make. Videos can be interesting and rewarding projects, if they are well planned and produced. It is the hope of the project's staff that Seattle's experience will help other jurisdictions interested in using video to describe their programs. 


\section{CHAPTER 1: PROGRAM DESCRIPTION}

The Seattle-King County area is recognized as a national leader in the management of hazardous wastes generated by small businesses and households. In 1982, the Municipality of Metropolitan Seattle (Metro) conducted one of the first household hazardous waste (HHW) collections in the United States. Using Metro's HHW

collection model, three suburban cities - Bellevue, Kent, and Tukwila - conducted annual one-day collection events. During the mid 1980's the region held a series of one-day HHW collection events drawing thousands of participants. In 1988, the City of Seattle opened its first fixed-site HHW collection facility. The following year, King County began operating a mobile HHW collection program to provide convenient disposal opportunities to its suburban and rural residents. The operation of fixed and mobile HHW collection programs has attracted a great deal of attention from jurisdictions throughout the United States that are interested in reducing the amounts of hazardous waste entering their residential waste stream.

HOUSEHOLD HAZARDOUS WASTE COLLECTION FACILITIES: FIXED-SITE FACILITIES

On October 25, 1988, the City of Seattle opened its first fixed-site HHW collection facility. The HHW facility is located at Seattle's south solid waste transfer station at the end of the driveway exiting the station's tipping floor. The driveway has been widened and striped to accommodate an unloading area for HHW beyond the normal truck traffic lanes. Residents pay a $\$ 5.00$ fee at the transfer station entrance and are directed to the collection area. Once at the collection area, residents using the HHW facility are directed to the unloading area where they are asked to identify the sources of the waste (only residential wastes are accepted) and to complete a short 
questionnaire. City staff quickly inventory the materials being dropped off, load the wastes onto a cart, and move them to the sorting area. Customers are not allowed to enter the waste sorting and storage area.

The sorting and storage area is a $60 \times 70$ foot fenced compound that sits on a bermed concrete pad. The pad is sloped to provide drainage to a dedicated surface-water containment system. Runoff collected in the containment system is visually inspected for contamination before being discharged into the sanitary sewer. A twelve-foot high metal canopy provides a covered work area for sorting and packaging the waste for disposal.

Two prefabricated hazardous waste storage buildings, capable of containing up to twenty-four 55-gallon drums, are on site. One storage building has two separate containnerat bays for poisons/pesticides, reactives, and heavy metals; and for corrosives/acids, bases, and oxidizers. Flammable wastes/oil-based paints, and chlorinatud and nonchlorinated solvents are segregated and placed in the second storage building. Each storage building is equipped with floor and ceiling ventilation systems, a chemical fire suppression system, non-sparking electrical system, explosion blow-out panels, and a 12-inch deep spill containment floor. An eyewash and safety shower are located on the outside wall of the building.

A third prefabricated building provides space for a small lab, offices, and worker breaks. The laboratory area is equipped with a refrigerator, stainless steel sinks, and an exhaust hood. Unknown wastes brought to the facility must be tested and identified before they will be accepted by the disposal contractor. Waste profiles and manifests are kept in computer files in the office.

Waste di posal is contracted to a licensed Treatment, Storage, and Disposal Facility (TSDF). Prior to waste pick-up, the following information must be recorded for all lab packed poisons, and for loose-packed mixed materials, such as corrosives and solvents: a) chemical composition or trade name for each item; b) size of the container; c) approximate amount of waste in each container, and, d) description of any unusual circumstances. A record of the number of containers in each loose-packed drum of paints and aerosols is also required. 
TSDF personnel review all recorded information, and verify that the company will accept the items on the list. Waste is picked-up from the facility once a week, with special pick-ups arranged as needed during the busy summer season.

\section{MOBILE HHW FACILITIES}

King County, Washington, operates HHW collections at 24 sites throughout the County using a mobile collection facility known as the Wastemobile. Site visits last two weeks, with collection on Thursday through Saturday. The Wastemobile is actually a truck and two trailers that contain all the equipment necessary to conduct hazardous waste collections. The truck is used to transport some of the equipment, and to remove waste from the collection site on a daily basis. One trailer is used to haul the majority of the equipment and serves as a secure storage area. The second trailer serves as an on-site office/lab.

The equipment brought to the collection site by this small caravan includes: portable berms, canopies, power generator, water system, emergency shower and eyewash, forklift, signs, tables, and enough fencing to enclose a 5,000 square foot area. Sites for the collections are selected for their ease of access, visibility, car waiting area, and hard working surface.

Similar to the permanent facilities, the Wastemobile is operated like a gas station. Residents drive up in their cars, and a collection staff person inspects and unloads the hazardo'ss waste. No fee is charged to users. Wastes are moved directly to a sorting table where they are identified and segregated for packing. Oils and fuels are bulked on site, while poisons and corrosives are lab- or loose-packed into 55-gallon drums. Unknown wastes are moved to the lab area where a "HazMat" kit is used to categorize the material.

The mobile collection system is labor-intensive because waste must be removed from the collection site every day. Originally designed to operate with a site supervisor and 
three technicians, heavily used sites have required that additional staff be hired. Power equipment, such as air wrenches and a forklift, also help to speed the packing process.

King County has contracted with a local TSDF to provide the fal ility's equipment and personnel, conduct the collections, and manage waste disposal. The TSDF contractor is responsible for: identifying and arranging each site; providing publicity and public education; managing site operations; and, transporting and disposal of the collected waste. The County's project manager is responsible for overseeing all aspects of the contractuai agreement with the facility operator including budgeting, scheduling, and coordination with local city officials.

\section{BUSINESS WASTE CONSULTATIONS}

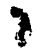

To assist businesses with the management of hazardous materials, Metro applied for and was awarded a $\$ 30,000$ grant by the EPA for establishing a Small Quantity Generators (SQG) assistance program. The monies were to be used to identify and implement methods for developing business networks which would promote environmentally safe disposal of small quantities of hazardous waste. As a result of the grant, the Waste Information Network (WIN) was formed to give advice and direction to the SQG assistance programs. WIN is a voluntary committee made up of regulatory agencies and business associations that are interested in helping businesses identify, reduce and dispose of their wastes. The innovative Business Waste Consultation program was developed with WIN's assistance.

Businesses are often regulated by several government agencies on the same issues, and these regulations may be in conflict. As an example, worker safety regulations may require a materials storage area be fenced and locked, while local fire codes may require that the area remain open and accessible in case of an emergency. Which agency's authority takes precedence?

Regulatory agencies are often unaware of the regulations promulgated by other agencies, and are unwilling to compromise their standards without official clarification. Conflicting requirements can leave the business confused and unsure of what changes 
should be made or what actions need to we taken. As a result, the business may be penalized and fined for non-compliance by one agency, after taking corrective actions required by another agency. The business is in a no-win situation. The imposition of conflicting regulations increases the cost of doing business and may even drive some businesses out of existence.

The goal of the Business Waste Consultations is to make government regulations more understandable cind consistent and help businesses improve their waste handling and disposal practices. First-hand information concerning the regulatory problems that businesses face is gathered by a consultation team, which inspects businesses that are typical of a trade. Working with local trade associations, individual businesses are recruited for consultation visits.

Businesses volunteering for consultations are asked to make their facilities available for a two-hour visit by a team of six regulatory agencies. To encourage cooperation, business owners are told that they will nc: be subject to enforcement action or fines. Only in instances of imminent danger are businesses required to take immediate action. Business owners are encouraged to point out problem areas and ask questions related to the safe handling and disposal of wastes. The consultations are an opportunity for businesses to ask technical experts for free advice. Participating businesses are also provided with a report outlining any identified problems and suggesting methods to correct them.

The consultation teams consist of representatives from federal, state, and local agencies that have health and safety regulatory authority over the business' operations. Team members are instructed to inspect the business' material and waste handling procedures and to identify problem areas. Interaction among team members during the inspections often points out regulatory conflicts that businesses confront. At the completion of each inspection, the team meets to discuss their findings and identify areas of regulatory conflict. Members are encouraged to resolve conflicting requirements by negotiating acceptable compromises. Each team member is asked to contribute his/her findings and recommendations to a report that will be sent to the business. Team 
members are also asked to contribute information to a waste handling resource guide for the specific trade inspected.

Resource guides are provided to the business association for distribution to their members. Business associations also are encouraged to include waste handling information in trade newsletters. The guide is also distributed by local agencie, uuring regular inspections, at trade fairs, and when requested from businesses. Hazardous waste resource guides have been developed for print shops, auto body repair shops, and small boat yards and marinas.

\section{SHARING INFORMATION}

To assist other government jurisdictions in gaining a better understanding of these programs, the City of Seattle, with the financial assi'stance of the Urban Consortium, has developed two video tapes. The video tapes were structured in a manner which brings the hazardous waste programs to life for the viewer. This was done by tracing the processes followed and methods used in each program. The video tapes potentially provide a low-cost way to observe how Seattle-King County's waste management programs are operated. 


\section{CHAPTER 2: LESSONS LEARNED}

While most of us have grown up with television, few people understand how video images work to convey a message. Video is a communication system that must be learned. Just as we learn to write, draw, or act, communicating well through video is an acquired skill. As with all communication skills, there are several rules that must be kept in mind when structuring a video presentation.

\section{DEFINING THE MESSAGE}

The first rule of producing a video is to define what you are trying to communicate and to whom. Videos are designed to evoke viewer reactions by presenting images and sound. Using video to convey a message and get the desired reaction requires that images and sounds be effectively coordinated. Unlike other media, video has total control over what the audience sees and hears, and when the images and sounds are used. If the video does not have a clearly defined message for a specific audience, the viewer will be confused and may not get any message or get the wrong message. Similarly, if the video is not structured to elicit a specific reaction from the viewer, identifying what images and sounds will be included may be difficult, and the video could appear to lack purpose. It is, therefore, necessary that the message, the audience, and the reaction being sought, be well defined and clearly stated.

IS VIDEO THE BEST MEDIA FOR THE MESSAGE?

Part of the definition process is to ask if video is the best media to convey the message to your audience. The answer will hinge on how the video is to be used (in 
training sessions, to promote a topic, or as entertainment), and the amount of money available for production. Identifying how and to whom the video is to be shown may reveal that another medium is more appropriate or could better reach the intended audience. If the message needs to be conveyed to a broad audience, and opportunities for group or mass viewings are limited, other media, such as printed material, may be preferred. In Seattle's case, video was selected to demonstrate the operation of the HHW facilities because there was an opportunity to show the video at a national conference where viewers could purchase copies of the tape for use with citizen groups and elected officials. Without a large, dispersed audience to view the program, the value of using video would have been limited.

Availability of funds tc produce the video is a second factor to be considered when selecting a medium. If money is iimited, it will be difficult to script, film, edit and distribute a "good" quality video. Equipment and production staff are expensivè, even when available through a government jurisdiction. If professional camera and sound crews must be hired, or editing studios rented, the cost will be upwards of one hundred dollars per hour. Pricing producticr, costs and estimating the budget necessary to produce the videos are important tasks to complete before selecting video as a medium.

\section{WHO'S THE AUDIENCE?}

Every video program has a target audience. Knowing who will be viewing the video and determining the desired viewer reaction will guide the entire production. Scripts, filming, editing and marketing will be directed toward getting the message to the intended audience. Influencing the audience is the reason for doing a video. The more information you gather about the audience, the more focused the presentation can be. Once the audience has been clearly identified, it is necessary to identify what reaction will be sought from the viewer. These two elements should be used to guide the rest of the decisions about the production. As production proceeds, keep in mind who the audience is and the reaction you want to stimulate. 


\section{NARROWING THE MESSAGE}

Defining a video's message is unique when compared to other media. Thousands of images and sounds can be used to convey a message. Selecting the right combination of images and sounds is difficult even with a defined audience and reaction. It is necessary to limit the information to be presented to the basics. Selecting the basic elements is more difficult than it might seem. During the initial meeting with the staff representatives from the HHW facilities, they were ceriain that a comprehensive presentation of their facilities could not be accomplished in a 10 to 12 minute video. Their concern was that too many elements and procedures had to be described. Again, the questions to be answered were "What does the audience need to know?" and "How do we want to present that information?" Technical details were not necessary; they would have clouded the presentation. Stripping away the day-to-day detail narrowed the focus to a series of 5 to 20 -second shots showing the fundamental elements. "Getting down to basics" is both the most necessary and most difficult step in developing a quality video.

Novices at producing and using video presentations need to remember that most visual images remain on the screen less than ten seconds. Every minute, six or more images can be shown. Coupling selected visuals with succinct sounds and narrative can portray detailed programs or stories in a short period of time. Television commercials that last 15 to 30 seconds are a good example of how images and sounci can be controlled to produce a defined reaction.

\section{SCRIPTS}

After the message, audience, and reaction have been identified and narrowed, a script needs to be written. Scripts are the blueprints of a video project. Developing a script is a planning process; this process involves determining which visual images can and should be shown, what sounds should be heard, and the order or position they should 
take in the video. Scripts also set the tone for the video by identifying the context in which the images are to be shown, i.e., positively or negatively. Like all good plans, scripts should be reviewed, commented on, and modified until the message is understandable and clearly presented.

Television script style brings together the visual and sound elements by presenting the information in parallel columns of text. The first column briefly describes what is to be shown, while the second column is the narrative and sound portion. Appendix A shows how the HHW script was written.

Scripts tend to be written in a casual or spoken voice. One tendency of individuals who are not familiar with script formats is to review and edit a script for its written style, rather than for its ability to accurately describe what the video is intended to portray. Government workers (who may tend to prefer a technical report writing style), are often the script reviewers; they may focus on phrasing, grammar and punctuation, rather than the video's content. It is sometimes helpful to suggest that the reviewer visualize the video images, while reading the script out loud to get a better understanding of the narrative fiow.

\section{SCRIPTS AND REALITY}

Successful videos get the viewer to accept the programs as reality. Simply stated, the images that are shown must be familiar enough to be real but different enough to hold the viewers attention. Viewers should be able to make personal mental statements while the video is being shown. "That's like my town", or, "I have had that problem", represent the kind of personal thoughts that make a video's message real to the viewer.

The people shown in the video should also seem real to the viewer. The Business Consultation Program video was targeted at operators of small-businesses. To make the issues real to a small business audience, interviews with business owners were included which highlighted the consultation process. Ordinary people tend to be more 
believable than professionals, but it can be difficult to get usable material from a "real" person. During the Business Consultation video, each business person was asked to respond on camera to a set of prepared questions. The first interviews were disasters: the business people were stiff and lifeless, and their responses were often rambling. Several techniques were used to overcome this problem.

One technique used to add life to the business interviews was to show the person at work or doing a task, while the narrator described the problem(s). Short, seven to ten second, interview clips were added to this segment to highlight the point being made by the narrator. The blend of action, narration and interviews kept the segment from slowing the pace and losing the audience's attention. A second alternative is to use the voice portion of the interview while showing images of the topic.

\section{GETTING THE MESSAGE ACROSS}

As with any visual or spoken media, information must be repeated and reinforced if the audience is to remember it. Most viewers can clearly recall only the information seer: $x$ heard in the last 10 to 15 seconds of a video. Video offers the producer an opportunity to state the issue and to show the viewer exactly what they mean. Wellplaced sound and visual elements can repeat the message without being obvious or appearing to be redundant. If it is important to get a message across to the audience, restating the information in a different way can be used to reinforce the point being made.

\section{SELECTING THE CAST}

Who should appear in a video is a major decision for most government productions. Some elected government officials feel an obligation to appear or want the exposure that a video may give them related to a topic of personal or professional interest. 
Although elected officials are usually well-informed, their expertise may be limited and they may not convey the desired message or tone. One solution is to structure the video such that interviews and/or official policy statements are limited or excluded. Another approach is to point out that significant amounts of time will be required in preparing for and taping the interview. If elected officials are to be used, having them prepare their presentation in advance can prevent them from coming across on camera as ill-informed, stiff or pompous.

\section{SCRIPT APPROVAL}

Script development is often a process that involves a broad range of interested individuals. All participants in the script's development and approval need to have a clear understanding of the project's purpose and goals. Convening a meeting that leads project participants through defining the message, determining the audience, and identifying the desired reaction sought car help build a consensus of what should be included in the video. Reaching an early consensus on the video's elements can speed the review and approval process. Once the script is approved, it is important that one staff person with decision-making authority be assigned to work with the production director.

The HHW and Business Consultation videos were directed by the City's Visual Information Specialist. After the scripts were approved by the City departments involved, decision-making became the responsibility of two people - a representative of the client department and the director. Final selection of filming sites, graphics, props, sounds, and visuals were made by those two individuals. It also was the staff/client's responsibility to work with the director to assure that scenes were consistent and accurate. During the taping of the HHW video it was important that correct props of both hazardous and non-hazardous waste be used. The realism and credibility of the video would have been endangered if incorrect products or cleaning methods were shown. 


\section{PRODUCTION}

It is the director's responsibility to select the best methods for capturing an image and building an impression. To arrive at the final product, a large amount of taping will take place and the best scenes to tell the story will be selected. Action is key to keeping the attention of the audiences. Several common mistakes that slow a presentation or lose the viewer's attention are conducting long interviews, selecting the wrong lighting or colors, or using monotonous sound and narration.

Many informational videos fall victim to the "talking heads" syndrome. "Talking heads" are long interviews that use a loosely framed shot of the speakers. The person speaking is often a professional or official who is discussing a technical issue or presenting the "official" version of a topic. Viewers tend to discount the interviewee's statement because they appear bureaucratic or contrived. Again, selecting believable people and staging an action sequence will keep the video from dragging.

A rule of design to remember is that the eye follows light. This rule also applies to a television screen, where the eye will focus on the lightest part of the screen. Hence, it is necessary to select shots that focus the eye on the important aspect of the scene. Lighting that is hard or glaring will cause the viewer to have a negative reaction, while soft, warmer lighting creates a more positive setting.

Mood is also effected by the use of colors. Bright colors show optimism, dull colors relate depression. Color can be important in creating a sense of action. Quick shots of colorful items that demonstrate a point will draw the viewers attention better than long monochromatic shots.

Selecting and mixing the correct sounds to create a reaction or convey a mood is the second major element of video. Again, the message being communicated and the identity of the target audience will effect the selection of the sounds, music, and narration. The audience for the HHW video was government officials seeking information; loud rock music would not have been appropriate. Sound also should be 
consistent with the images being shown, or the viewer will be confused by the inconsistencies. The sound of tires squealing may be consistent with a video of an auto race but is inconsistent for a safety video concerning the transportation of hazardous waste.

\section{EDITING}

Editing is the process of combining the visual and sound elements to effectively tell a story or convey a message. The editing process begins by reviewing and logging the time codes for all of the scenes recorded. From this $\log$ the basic editing decisions can be made by selecting the best scenes to tell the story. Once the basic decisions have been made, an off-line version of the productions is made. Off-line editing allows the director to "try out" various scenes, effects and sounds to evaluate if they work together effectively. With program continuity agreed upon by the director and client, final (on-line) editing can be scheduled to tighten scenes, add background sound, blend scenes, and add special effects. Sophisticated on-line editing equipment requires constant supervision by an engineer and is therefore extremely expensive to use. By preparing an off-line version of the production, on-line editing time can be minimized and studio costs lowered.

Editing a video production to tell a story that flows smoothly and will hold the viewers interest is a difficult and time consuming process. For a "gi:sd" quality production it is necessary that the director have a demonstrated ability to use, video technology to translate a script into story that is believable to the audience. The editing is the most technical process of video production. The client should trust the director's judgment and be comfortable with the director's technical ability to use and control the media.

\section{MARKETING STRATEGIES}

Video can be marketed by doing it yourself, or hire a distributor. The City of Seattle choose to develop its own marketing plan and to implement its strategy using project 
staff. This option was selected because a national convention on household hazardous waste was to be held in the City, providing a ready market. As a means of lowering marketing costs, the City previewed the videos at the convention and then accepted orders with payments from buyers. Pre-selling the videos increased the number of tapes to be initially duplicated and lowered the per-unit price of the product.

Additional marketing for the videos is being arranged with the Urban Consortium and Public Technology, Inc.. National marketing of the videos may include a brochure/mailer that could be sent to jurisdictions describing the product. Mailing lists could be obtained from associations of city and county officials. Advertising in national solid and hazardous waste trade journals is another promotional method being considered.

\section{CONCLUSION}

Producing a "good", quality video requires complete and thorough planning. The message, audience, and reaction being sought needs to be well-defined, and established goals should be kept in mind while producing the video. Images and sound must be selected, blended and edited in a consistent manner to make the story being told real and personal to the viewer. Lighting, colors, actors and settings must be chosen to show action, while enhancing the message. Planning brings all of these elements together to assure that the message is clearly conveyed to the audience and the desired reaction occurs. 


\section{References}

Patterson, D. August 1991. Personal communication.

Schroeppel, T. 1990. Video Goals: Getting Results with Pictures and Sound.

Whittaker, R. 1989. Video Field Production. Mayfield Publishing Company, Mountain View, CA.

Winston, B., and Keydel, J. 1986. Working with Video: A Comprehensive Guide to the World of Video Production. Knowledge Industry Publications, Inc., White Plains, NY. 
APPENDIX A

VIDEO SCRIPT 
Seattle Department of Community Development

$$
\begin{aligned}
& \text { - Oa S-Dori.jorrson Direcior } \\
& \text { ¿ama- } 3 \text { Rice Mayor }
\end{aligned}
$$

HOUSEHOLD HAZARDOUS WASTE Ot.P

VIDEO:

montage of hazardous waste product use...landfills, garbage, seagulls, bulldozers etc....

people burying products..

wide city life shot.....

Duwamish waterway area (evidence of industry \& poluution)....

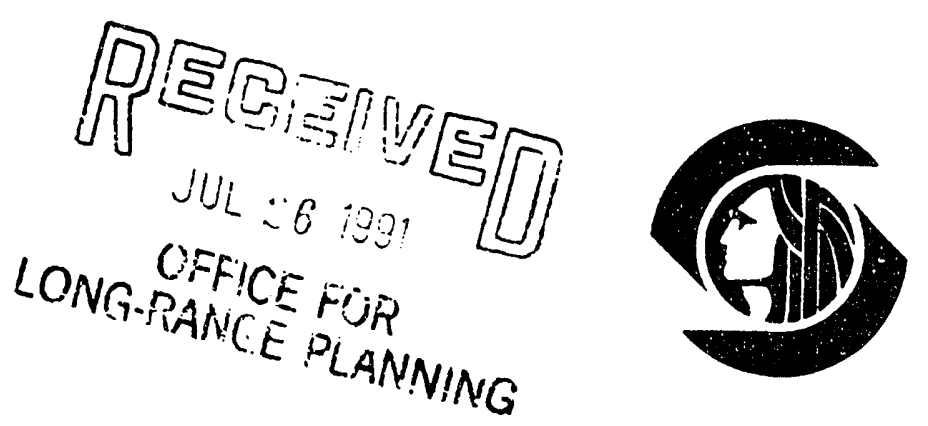

AUDIO: Wo, Music, Natural

(music over :60) ...

EVERY YEAR SOME 100 MULION AMERICAN HOUSE-

HOLDS CONSUME BIHTIONS OF DOLIARS IN PRODUCTS

CONIAINING HAZARDOUS WASTE.

ANNUALLY, THESE PRODUCTS CONIRTBUTE NEARLY

ONE MIILION TONS OF HAZARDOUS WASTE TO OUR

NATION'S GARBAGE.

AMERICANS SPEND CLOSE TO SIX BIILION DOLLARS

YEARLY ON AUTONOTTVE CHEMICALS IITEE ANTI-

FREETE AND OIL - WHIIE OUR APPETITE FOR

HOUSEHOTD CIEANERS TOPS TWENTY BIIIION

DOIIARS. BIILIONS MORE APE SPENT EACH YEAR

ON BATTERIES, ADHESIVES, PAINT AND

PESTICIDES.

IN AN AVERAGE SIZE CITY OF 100,000 PEOPIE, ABOUT FOUR TONS OF TOIIET BOWL CLEANER, 14 TONS OF HOUSEHOID CIEANSERS, AND 3 AND $\frac{1}{2}$ TONS OF OIL WIIL BE DISCHARGED INTO CITY DRAINS EACH MONIH. ONER THE YFARS, THE TOXIC WASTE OF MUDETNN ITVING HAS LEFT ITS MARK ON THE COUNIRYSIDE FROM SOURCES BOTH COMMERCIAL AND INDIVIDUAL. 
Page Two

Hazardous Waste - OtP

VIDEO:

exanple of sqg business... lgovt facilities...public works garage, Metro bus garage, school labs)...

Eil shelf of hane storage shed...

person collecting waste products around home (maybe loading car)...

Metro file footage?

existing footage on City

round-ups... technisal coordinating

comisittee...
AIDIO:

ALTHOUGH SOME 98\% OF HAZARDOUS WASTE COMES FROM MAJOR INDUSTRIES - OF THE REMAINING $2 \%$ TWO-THIRDS IS PRODUCED BY SMALL QUANTITY GENERATORS SUCH AS AUTO BODY SHOPS, DRY CIEANEIR, AND OIHER BUSIIESSES. THE SOURCE OF THE OTHER THIRD IS FOUND MUCH CLOSER TO HOME - IN THE DANGEROUS DISCARDS OF THE MIIIIONS OF HOUSEHOLDS ACRCSS THE LAND. THE PATH TAKEN IN WASHINGION'S PUGET SOUND REGION TO ADDRESS HOUSEHOLD HAZARDOUS WASTE DISPOSAL BBGAN IN 1980. AT THAT TIME, AN AREA DISPOSAT, COMPANY BEGAN AOCEPTING WASIE FROM LOCAL PESIDENIS WHIE THE SEATTLEKING COUNTY HEPLTH DEIARIMENT INITIATED A PIAN TO RECETVE PESTICIDES AND HERBACIDES FOR DISPOSAL.

IN 1982, THE MUNICIPALITY OF METROPOLITAN SEATTLE (METRD), CONDUCTED ONE OF THE FIRST HOUSEHOWN HAZARDOUS WASTE COLIECTIONS IN THE UNITED STATES. SHORILY AFTER, USING METRO AS A MODEI, THREE SUBURBAN CITIFS, BEILEVUE, KENT AND TUKWIIA, INSTITUTED ONE-DAY COLIECTION EVENTS OF THETR OWN.

IN 1985, THE WASHINGION STATE LEGISLATURE REQUIRED COMMNITIES TO DEVEIOP LOCAL HAZARDOUS WASTE MANAGEMENT PIANS.

COMMNITIES IN KING COUNIY JOINED TUGEITER Ii 
Page Three

Hazardous Waste - OLP

VIDEO:

file footage on round-ups...

southend collection facility/

series of dissolves of Wastemobile being set-up/
AUDIO:

PREPARING A COOPERATIVE PLAN.

FROM 1987 TO 1989 - REGIONAL HAZARDOUS WASTE ROUND-UPS WERE CONDUCTED IN MANY COMMUNITIES IN KING COUNTY. MEANMHUIE, INITER-COVIERAMENIAL PLANNING TO COOADINATE GOALS AND OPERATING STRATEGIES CONTINUED AMIDST THESE ONE-DAY COTIECTION EVENTS. IN 1988 - THE SOUTHEND OPENING OF SEATTLE'S FIRST PERMANENT HOUSEHOLD HAZARDOUS WASTE COLIECTION FACIIITY AND THE INITIATION OF KING COUNTY'S MOBILE COLIECTION PROGRAM SPETIED THE START OF COORDINATED REGIONAL MANAGEMENT.

(SOT fram official an need \& goals of program).

THE CITY'S CHOICE OF A PERMANENT FACIITTY AND THE COUNIY'S DECISION TO GO WITH THE MOBIIE OPTION, WETEE EACH MADE WITH THE PARTICULAR ADNANTAGES AND DRAMBACKS IN MIND.

KING COUNTY'S TRAVEILING WASTEMOBIIE IS A FACIIITY CONIRACTED THROUGH A LOCAL, INDEPENDENT DISPOSAL COMPANY. SINCE MOBIIE SITES ARE MORE CONVENIENT THAN FIXED SITES - PUBLIC PARITCIPATION AND WASTE COLIECTION ARE GREATER, WHICH IN TURN - RAISES PROGRAM COSTS. THUS, MOBIIE PROGRAMS ARE GENERALLY HANDLING 
Page Four

Hazardous Waste - OLP

VIDEO:

AUDIO:

HIGHER VOLUMES AND SPENDING MORE FOR HAZARDOUS WASTE DISPOSAI. THE WASTEMDBIIE ITSEIF IS NOT ACTUALLY A VEHICIE BUT A SERTES OF TRAIIERS CONIAINING AN ELECTRIC GENERRATOR, A WATER SYSTFM, A FIRST AID SIATION, PROTIECTIVE CLOTHING, SPIIL CONIARNENT, AND OIHER EQUIPMENT ALL SET UP UNDER CANOPIES BY THE CONIRACTOR.

THE SITES OOCUPY ABOUT 5,000 SQUARE FEET AND ARE PRE-SEILCTED, GENERALLY IN CHURCH, FIRE DEPARTMENT OR MAIL PARKING IOTS. THE OPERATION MUST TAKE PLACE AKAY FROM STORM DRAINS AND THE AREAS ARE SECIRED BY MEANS OF PORIABLE FENCING.

THE PERMIT PROCESS FOR THE WASTEMOBIIE IS MINIMAL WIIH LITTLE RED TAPE BEYOND THE FIRE OR OONDITIONAL USE PERMIT. THE WASIEMOBIIE IS AVALIABLE AT 24 LOCATIONS EACH YEAR THROUGHOT THE 2,000 SQUARE MIIE COUNIYWIDE SERNICE AREA. THE GOAL IS TO BE WTIHIN 5 MIIES OF AIL POTENTIAL CUSTOMERS AT LEAST TWO TIMES EACH YEAR. THE STAYS EXTEND 2 WEEXS PER SITE AND THE EVENTS ARE PROMOTED THROUGH ADVERTISTR AND NEWS COVERACE. COLLECTIONS TAKE PLACE THURSTAYS, FRIDAYS, AND SATURDAYS,

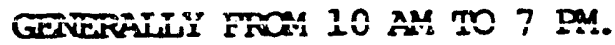


AUDIO:

EMPLOYEES, AND SITES ARE RUN LTKE FULL SERVICE GAS SIATIONS. EACH VEHICIE REQUIRES AFOUT TWO MINUTES FOR EMPLOYEES TO PROCESS AND CN SOME OCCASIONS, THIS PROCESSING MAY INVOLVE MORE THAN 200 CARS PER DAY. SOME ITEMS LIKE OII, LATEX, AND SOLVENTS ARE BUKKED in 55 GALION DRUMS ON STTE.

AT THE END OF EACH OPERATING DAY, ALL HOUSEHOLD WASTE COLLECTED IS TRUCKED AWAY IN DRUMS BY THE CONTRACTOR. (SOT worker on packing haz. waste)... southend facility THE CITY OF SEATTLE'S SOUTHEND FIXED FACIIITY WAS DESIGNED AND CONSTRUCTED OVER A 24 MONTH PERTOD. THE STRUCTURE WAS BUIIT ON CITY PROPERTY AT THE TRANSFER SIATION, AND IS STAFFED BY TWO CITY EMPLOYEES. HOUSEHOLD HAZARDOUS WASTE IS ACCEPTED THURSDAYS THROUGH SUNDAYS DURING THE DAY AND EARLY EVENING HOURS - THROUGHOUT THE YEAR.

THE LAYOUT INCIUDES PRE-FAB STORAGE AND OFFICE BUIIDINGS - A DRIVE-THRU DROPP OFF AREA - AND A ROOFED AND PAVED WORR SECTION. STORAGE IS MAINTIATNED IN 55 GALION DRUMS IN THE EXPLOSION PROOF FRE-FABS WITY CHEMICAL FIRE SUPPRESSION AND CLOSED SIMPS UNDER THE 
Page Six

Hazardous Waste - OP

VIDEO:

council meeting/ siting process

northend site neighborhood footage illustrative of concerms/
AUDIO:

FLOORS. THE COLIECTED WASTE IS TRANSPORTED TO THE END DISPOSAL COMPANY ON A WEEELLY RATHER THAN THE WASTEMOBILE'S DAIIY BASIS. (SOT on availability of first aid...accidents). THE FIXED FACIIITY IS INIENDED TO SERVE CUSTOMERS IN DENSER URBAN AREAS. SINCE IT IS PERMANENTLY IN PLACE, HONEVER, THERE IS LTTTLE PROMOTIONAL NEWS VALUE AS THERE IS WHEN THE WASTEMOBIIE BEGINS COLUECTION IN A NEW LOCATION.

ALTHOUGH THE CITY AVOIDS THE COUNTY'S PROCESS OF CONTINUAL SITING FOR ITS MOBIIE FACIITTY, SITING A PERMANENT FACIIITY CAN BE A DIFFICULT AND COSTHY ENDEAVOR. SOME OF THE ENNIRONMENTAL AND NETGHBORHOOD IMPACTS THAT CONCERN RESIDENTS AND SITING DACISION-MAKERS INCLUDE - ROUTING WASTE CARRYING TRUCKS OFF RESIDENTIAL STREETS TRAFFIC - THE AESTHETICS - AND RISK OF SPIIIS, FIRES, EXPLOSIONS, FLOODING AND STORM WATER DISCHARGE. (SOT on siting difficulties). BOTH PERMANENT AND MOBIIE FACILTTIES ARE SUBJECT TO STATE AND LOCAL REGULATIONS WHICH CAN INCLUDE LOCAL IAND USE, FIRE, AND STATE SOLID WASTE HANDLING PERMITS. 


\author{
Page Seven \\ Hazardous Waste - OLP \\ VIDEO:
}

wastemobile in operation

loading waste drums
AUDIO:

SINCE THE WASTEMOBIEE IS DESIGNED TO MEET HOUSEHOLD DISPOSAL NEEDS ONLY, AUTOS BRINGING APPARENT COMMERCIAL WASTE ARE REFUSED ENTRY AND GIVEN INFORMATION ON HAZAFDOUS WASTE DISPOSAL SERVICES AVATIABLE FOR BUSINESSES. SOME 598 OF THE WASTEMDBIIE PRODUCT IS RECYCTED OR DETOXIFIED. ASIDE FROM RECYCLTING, THE END OPTIONS FOR DISPOSAI ARE TO BURY, NEUTRALIZE, OR INCINERATE THE WASTE - PER REGULATIONS. THIS IS HANDLED BY A LICENSED DISPOSAL COMPANY. CITY AND COUNIY FACIIITIES REJECT RADIOACITVE WASTE - ASBESTOS - EXPLOSIVES - AND ALL BUSINESS DISCARDS.

THE DECISION ON A MOBIIE VERSUS FIXED COLLECTION PROGRAM IS DEPENDENT UPON THE NEEDS OF THE' SERVICE AREA AND THE LEVEX OF CONVENIENCE TO BE PROVIDED. MOBIIE FACIIITIES TEND TO HAVE HIGHER OPERATING COSTS DUE TO CONVENIENCE AND BECAUSE THE WASTE COLLECTED MUST BE TAKEN OFF SITE NIGITLY.

aN THE OTHER SIDE, FIXED OOLIECTION STTES TEND TO EXPERIENCE HIGHER COSTS ASSOCIATED WITY THE SITING PROCESS. THEY ALSO TEND TO HAVE MORE INITIAL CAPIIAL COSTS SUCH AS THE 
Page Eight

Hazardous Waste - OIP

VIDED:

Seattle site/

northend facility under construction/

a on vaste disposal/

dialogue with employee \& public/

purchasing products/ move fram taxic to non-toxic...
AUDIO:

LAND, THE BUIIDINGS, AND PAVED SURFACES, ETC. . THESE COSTS, HOWEVER, ARE AMORTIZED

ONER 15 TO 20 YEARS, CUTTING THE LONG-TERM EXPENDITURE.

SINCE THE INCEPTION OF COORDINATED REGIONAL WASTE MANAGEMENT IN 1989 - THE EMPHASIS HAS BEEN ON PLANNING, DESIGNING, AND IMPLEMENTING COLIECTION FACIIITIES. WITH THE CURRENT OPERATING HISTORY, SUFFICIENT INFORMATION NOW EXISTS ON AMDUNTS AND TYPES OF WASTE COILECTED TO EXPLORE ALTERNATIVE DISPOSAL METHODS. IN THE FUTURE THIS MAY INCLULE MORE ON-SITE PROCESSING AND TREATMENT OF WASTE TO DECREASE DISPOSAL COST. COLILCTION FACHITTIES ALSO OFFER A GOOD OPPORTUNITY TO EDUCATE THE PUBLIC ABOUT WASTE REDUCTION. CHANGING PEOPLE'S PURCFASING AND USAGE PATTERNS OF HARMFUL CHEMICAIS IS AN IMPORTANT EJEMENT IN THE OVERALL TASK. CONTINUED SUOCESS IN CONIROLLING HAZARDOUS WASTE WIIL REQUIRE MORE THAN A DECISION ON WHEIHER TO GO WITH A FIXED OR A MOBIIE SITE. VARIAITONS IN THE OPERATION OF THESE FACIITTIES ARE CURRENTLY BEING CONSIDERED TO INCREASE EFFICIENCY AND EFFECTIVENESS. SOME OF THESE INVOLVE TARGETTING HIGH VOLUME WASTE ITEMS LIKE PATNT AND OII - ESTABILISHING 
Page Nine

Hazardous Waste - OLP

VIDEO:

series of shots segue fram toxic to non-toxic use around the hame...

household product use...

contimue same of opening mantage at conclusion... credits over
AUDIO:

SATELLITE COLLECTION WITH CENTRALIZED

PROCESSING - MIXXD PERMANENT AND MOBIIE

FACILITIES - AND EVEN SINGLE DAY

COLIECTIONS.

THE GOAL OF CONIAINING AND CONIROLIING

DISPOSAL OF EVER INCREASING HOUSEHOLD

HAZARDOUS WASTE IS QUITE FORMIDABLE.

FORIUNATELY FOR THE ENVIRONMENT, HOWEVER,

THE CONCERN HAS CAPTURED OUR ATTENTION.

THE CITY'S SECOND PERMANENT FACIIITY WIIL

SOON BE OPERATIONAL IN SEATTLE'S NORTHEND -

WHIIE THE COUNTY PIANS TO EXPAND THEIR

PROGRAM WITH ADDITIONAL WASTEMOBIIES.

WITH BIILIONS OF DOLLARS IN POISONOUS

PRODUCTS ENIERTNG OUR ENVIRONMENT EACH

YEAR - THE TIME IS UPON US TO RESPONSIBLY

DEAL WITH THE LEFTOVERS.

patterson (revised)

7-11-91 
Additional copies of this report, "Sustainable systems Rating Program" are available from:

Publications and Distribution

Public Technology, Incorporated

1301 Pennsylvania Avenue, N.W.

Washington, D.C. 20004

For additional information concerning this project, please contact:

Henry Sharpe, Manager

Environmental and Transportation

Planning

City of Seattle

Office for Long-range Planning

6004 th Avenue, Room 200

Municipal Building

Seattle, WA 98104-1873

(206) 684-8056 


\section{Publications Price List--UCETF Reports}

TITLE

PRICE

ITEM

Hydraulic Waste Energy Recovery: A Technical Report

15.00

90-318

A Regulatory Framework for Alternative Fuels and Transportation Management Services

15.00

90-316 Alternative Vehicle Fuels: A Demonstration Project 15.00

90-314 Energy Efficiency in Public Housing 15.00

89-330 Analysis of Programmatic Fleet Conversion to Ethanol Blends 15.00

89-325 An Alternative Fuels Evaluation System for Fleet Vehicles 15.00

89-323 Dual Fuel Conversion Demonstration and Technology Transfer Project 10.00

89-321 Summary of Low and Moderate Income Residential Energy Conservation Programs 15.00

89-315 A Case Study in the Pursuit of Urban Energy Efficiency

89-314 Communicating with the Public About Environmental Health Risks: A Case Study 13.00

89-313 Evaluation and Comparison of Selected Household Hazardous Waste Collection Facilities 15.00

89-311 Yard Waste Recycling Study: A Pilot Study 15.00

89-310 Sludge Storage Lagoon Biogas Recovery and Use, Volume 1

89-307 Proceeding: 1989 Electric Utility Franchise Conference 20.00

89-306 Reducing Electricity Demand Through Energy-Related Efficient Construction 15.00

89-304 Modernization of Lighting in Municipal Auditoriums 15.00

89-303 Wastewater Treatment Process Energy Optimization 13.00

89-301 Implementation of Alternative Technologies through the Assessment of Energy Markets 14.00

88-322 Marketing Energy Efficiency Programs to Commercial and Industrial Firms: Lighting Incentives and 15.00

88-321 Urban Energy Management Today: Ten Year Compendium of UCETF Programs 10.00

88-319 Integrating Energy Efficiency Into Municipal Purchasing Decisions: Computerizing Procurement 15.00

\begin{tabular}{|c|c|c|}
\hline $88-318$ & Household Hazardous Waste: Implementation of a Permanent Collection Facility & 20.00 \\
\hline $88-317$ & Hazardous Waste as an Energy Manager's Issue & 15.00 \\
\hline $88-316$ & Household Hazardous Waste Management Planning & 15.00 \\
\hline $88-312$ & Summary of Small Business Energy Conservation Programs & 15.00 \\
\hline $88-310$ & The Earth-Coupled Heat Pump: Utilizing Innovative Technology in Single Family Rehabilitation & 15.00 \\
\hline $88-309$ & Energy Planning for Economic Development & 18.00 \\
\hline $88-308$ & Conversion of Resource Recovery Steam to Hot and Chilled Water Systems & 10.00 \\
\hline $88-306$ & HVAC Equipment Replacement for Best Size and Efficiency, Transfer Report & 15.00 \\
\hline $88-305$ & Cogeneration and Cooling in Small Scale Applications & 15.00 \\
\hline $88-304$ & Energy Master Planning: Innovative Design and Energy Analysis Services for New Commercial & 22.00 \\
\hline $88-303$ & Energy Efficient Building Design: Guidelines for Local Government & 15.00 \\
\hline $88-302$ & Direct Digital Control of Air Washer Cooling System & 15.00 \\
\hline $88-30 \mathrm{i}$ & Feasibility Study of Transportation Management Strategies in the Poplar Corridor, Memphis, Tennessee & 18.00 \\
\hline $87-327$ & Energy Effiicient Urban Cooling Technologies: 1st National Conf. & 20.00 \\
\hline $87-324$ & Memphis Area Rideshare & 15.00 \\
\hline $87-317$ & Joint City Government/Utility Partnerships to Reduce Business Costs & 15.00 \\
\hline $87-314$ & The Impact of Budgetary Incentives on Energy Management & 15.00 \\
\hline
\end{tabular}


Publications Price List-UCETF Reports TITLE

PRICE

20.00

15.00

20.00

15.00

18.00

20.00

40.00

20.00

20.00

20.00

7.50

86-314 Inhibition of Respiration in Activated Sludge by High Carbon Dioxide Concentration

86-313

Water Supply System Energy Conservation Through Computer Control

18.00

20.00

15.00

15.00

20.00

20.00

15.00

15.00

15.00

15.00

18.00

10.00

15.00

10.00

18.00

15.00

15.00

15.00

18.00

18.00

15.00

15.00

18.00

85-307 Thermal Storage Strategies for Energy Cost Reduction

84-325 Shared Savings in the Residential Market

84-324 Methanol Use in Vehicle Fleet Operations: Barriers

20.00

$84-322$

Energy Management and Technology for Urban Governments

15.00

$84-321$

Hydrate Process for Waste Water Treatment Plant Sludge Dewatering 


\section{Publications Price List-UCETF Reports}

\section{TITLE}

ITEM \#

Development of Computerized Inventory and Maintenance System for Municipal Street Lights

84-315 Facilities Energy Monitoring System

84-314 Application of Mini-Van Technology to Vanpool Services

84-312 Implementation Methods for an Integrated Energy System

84-311 Feasibility of Water-Based District Heating and Cooling

84-310 Budgetary Incentives for Municipal Energy Management

84-309 Central Energy Systems Applications to Economic Development

84-308 On-Site Cogeneration for Office Buildings

84-306 Analysis of Municipal Bus Operations for the Advancement of Fuel Cell Technology

84-305 Computer Based Maintenance

84-304 Innovative Finance Plans for Privately Owned Waste/Vol. 2

84-303 Innovative Finance Plans for Privately Owned Waste/ Vol. 1

84-301 Coordinating Preventive Maintenarice with Energy Management

83-319 The Rehabilitation and Retrofit of Older Houses to Superinsulated Standards

83-318 Developing Sources and Techniques for Alternative Financing of Energy Conservation

83-316 Hydrate Process for Dewatering Sewage Sludge

83-315 Financial Planning for District Heating: Brooklyn Navy Yard

83-314 Memphis Area Rideshare On-Line Information System

83-313 Renovation Opportunities for Steam District Heating Systems

83-312 Initial Assessment of District Heating and Cooling

83-311 Energy Conservation Through Computerized Automation

83-309 Development of an Energy Park: Issues and Implementation Options

83-308 Alternative Uses for Digester Methane Gas

83-307 Innovative Financing and Incentive Package to Reduce Energy

83-305 Multi-Jurisdictional Planning for District Heating and Cooling

83-303 Improving Energy Management and Accountability in Municipal Operations

82-320 Utilization of Felled City Trees as Supplemental Boiler Fuel

82-319 Methanol Use in Vehicle Fleet Operations: Comparisons

82-317 Microcompter Tools for Trans. and Residential Energy Conservation

82-316 Reduction of Impediments to Alternative Energy Use

82-315 Reducing Regulatory and Financial Impediments to Energy Conservation

82-314 Integrating Energy Management with Economic Development

82-313 Energy Conservation and Economic Development

82-310 Municipal Technologies

82-307 Strategies to Improve Community Energy Use Practices

82-306 Energy Conservation In Water Treatment

82-305 Development of an Energy Action Plan: Participating Approach

82-303 Energy Economic Development
PRICE

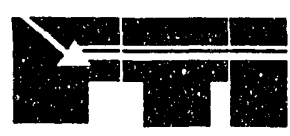

15.00

15.00

18.00

10.00

15.00

22.00

20.00

15.00

15.00

15.00

15.00

15.00

15.00

15.00

20.00

10.00

15.00

18.00

18.00

20.00

18.00

15.00

25.00

15.00

10.00

15.00

7.50

15.00

20.00

20.00

20.00

20.00

10.00

20.00

10.00 
Publications Price List-UCETF Reports

ITEM \#

82-302 Public Housing Energy Efficiency Through Private Financing

82-300 Developing an Energy Management Tracking System

81-328 Matching End Use Energy Needs to Source Possibilities

81-327 Development of a Hydrogen-Fueled Mass Transit Vehicle s

81-326 Operational and Maintenance Guidelines for Reducing Energy Consumption

81-324 Energy Management for Small Business

81-320 Energy Datá Gathering, Analysis, and Review System

81-318 Fuel Management and Planning System for Local Government

81-316 Production of Ethanol from Cellulosic Fraction

81-313 Metro-Dade County Comprehensive Energy Emergency Plan

81-311 Developing Energy Emergency Prepardness 15.00

81-310 Simplified Methodology for Community Energy Management 20.00

81-309 Energy Management: The Public Sector 15.10

81-307 Municipal Technical Assistance-Energy Monitoring 6.00

81-306 New Technology Demonstration 10.00

81-305 Technology Transfer: Unit Report from the Energy Task Force 15.00

81-304 Development of Local Energy Management Preparedness 10.00

81-303 Municipal Energy Management 10.00

80-314 Methodology for Energy Impact Analysis of Urban Development Projects 15.00

80-313 Evaluation of Landfill Gas as an Energy Source 15.00

80-309 Decision Process for the Retrofit of Municipal Buildings 20.00

80-308 Primary Urban Energy Management Planning Methodology 7.50

80-306 Local Government Use of Thermography for Energy 15.00

79-300 Planning for and Purchasing Computer Technology 6.50 


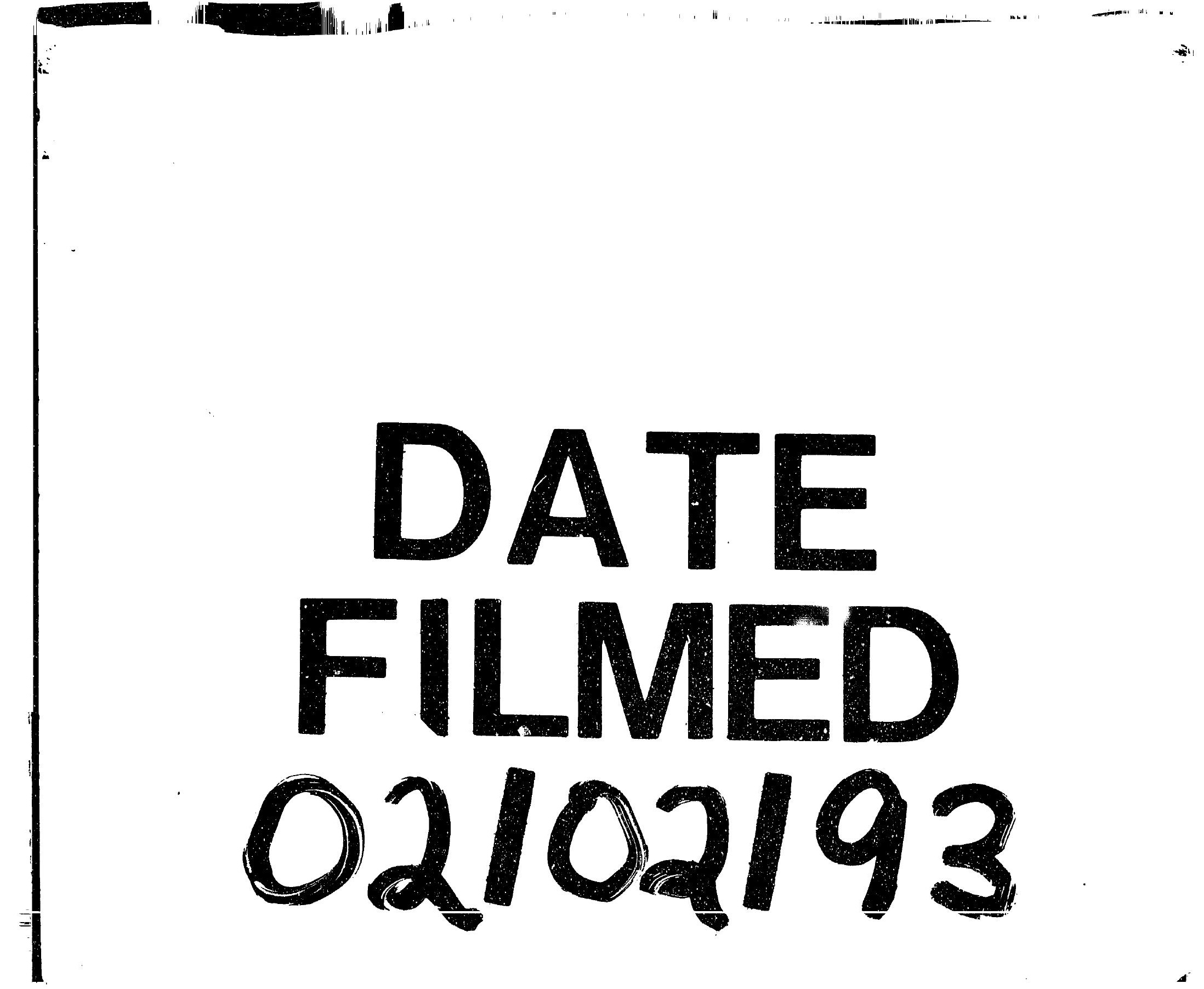


